\title{
Task-based Language Teaching: Task-based Speaking Activities Used in EFL Classrooms at Tertiary Level
}

\author{
Le Van Tuyen ${ }^{1 *}$, Huynh Hoai $\mathrm{An}^{2}$ \\ Ho Chi Minh City University of Technology (HUTECH)-Vietnam
}

*Corresponding Author: Le Van Tuyen, Ho Chi Minh City University of Technology (HUTECH)-Vietnam

\begin{abstract}
Task-based language teaching (TBLT), a language teaching and learning approach, has been received much concern from language educators and researchers in different contexts for the last three decades. With a desire for making a valuable addition to the literature, this study, therefore, aims to explore how EFL teachers at a private university in Ho Chi Minh City -Vietnam (henceforth called PUH) perceive TBLT principles and discover what EFL teachers' and students' perceptions of the types and advantages of task-based speaking activities (TBSA) used in EFL classes at tertiary level. The study involved 383 students and 10 EFL teachers. Both quantitative and qualitative data was obtained through two instruments, namely the questionnaire and classroom observation. For analyzing the data collected, descriptive statistics and content analysis were employed. The results of the study revealed that most of the EFL teachers have a good understanding of TBLT principles; most of them and their students clearly know about the types as well as the advantages of TBSAs used in EFL classes. More interestingly, the findings of the study also revealed that TBSAs have been often implemented in EFL classes; and it can be confirmed that all of the teachers have applied TBLT in their instruction. This study is expected to shed light on the implementation of teaching speaking skills in the PUH context and in other similar contexts.
\end{abstract}

Keywords: TBLT, Task-Based Speaking Activity, Advantages, TBLT Principles, Tertiary Level

\section{INTRODUCTION}

Recently, a shift towards more communicative and eclectic methods and approaches of foreign language teaching in Vietnam has led to a change in classroom time for students to actively communicate with one another. As students expect to find learning speaking challenging, it is required that EFL teachers find out innovative ways of teaching speaking skills. Moreover, Ur (2006) claimed that of the four language skills (listening, speaking, reading, and writing), speaking seems to be the most important, but challenging. Speaking is an interactive process of constructing meaning that involves producing, receiving and processing information (Burns \& Joyce, 1997). Students need to develop different skills and strategies to keep conversations going on. It is required that they not only know how to produce specific points of language such as grammar, pronunciation, or vocabulary, but they also understand when, why, what and how to talk.

In addition, it is also a commonly recognized fact that achieving proficiency in foreign language speaking in classroom conditions is not an easy task. This difficulty is basically due to the students and inadequate frequency of speaking opportunities in the classroom in comparison to the abundance of natural varieties and genres of oral communication (Nation, \& Newton, 2009).

Nonetheless, the skill of speaking is not automatically transferable from the speaker's first language into the target language (Thornbury, 2007). In cases where there is little chance for oral interaction outside the classroom, it is thus imperative to optimize the classroom time available and create opportunities for the development of students' speaking skills. One of the best ways is using a procedure based on the use of speaking tasks as the core unit of planning and instruction in language teaching to enhance EFL students' speaking ability (Richards \& Rodgers, 2001).

TBLT has been considered to create a real purpose for language use and provide a natural context for language education through the use of different tasks (Willis, 1996). TBLT is a language teaching and learning approach which has been used since 1980s. It is accepted by linguists and foreign language teachers, researchers and curriculum developers for last three decades (Breen, 1987). That is because a language is best learned through using it (Thornbury, 2007). Lee (2000) defines "a task as a 

Level

classroom activity or exercise that has an objective obtainable only by interaction among participants." The focus of a task is on meaning. Moreover, a task requires students to comprehend, manipulate and produce target language as they perform the set task, involving real-world language (Nunan, 2004).

Willis (1996) indicates that TBLT has a various advantages such as it makes students more confident in trying out whatever language they know, gives them opportunities to negotiate meaning and interact with their classmates, engages them in using language purposefully and cooperatively, gives them chances to try out communication strategies so that they can develop confidence to achieve communicative goals and enhance language knowledge.

Nevertheless, more importantly, it is required that language teachers who want to implement TBLT successfully have sufficient knowledge about the instructional framework related to its plan, procedure, and assessment. Researchers have developed into a detailed practical framework for the communicative classroom in which learners perform task-based activities through cycles of pre-task preparation, task performance, and post-task feedback through language focus (Willis, 1996). The components of the task-based learning framework lead teachers to follow teaching steps effectively because task-based learning employs sequences that differ from other teaching methods. Researchers identify five major components of a task including: Goals serve as a guideline in the overall process of task performance and provide a point of contact between the task and the broader curriculum (Nunan, 2004); input data can be derived from a wide range of sources in a real-world context and should reflect the learners' needs and interests, thereby positively encouraging the use of target language; classroom setting refers to a certain environment, in which every task is the target language performed. In relation to classroom arrangements, Wright (2005) suggests the different ways in which learners might be grouped physically based on individual, pair, small group, and whole class mode; activities refer to what is carried out for the students to perform in class to use the target language; and assessment of task performance represents an attempt to get an accurate picture of students' communicative abilities. It involves either the observation of behavior in the real world or a simulation on life activity in a pedagogical setting (Norris, Hudson, \& Bonk, 2002).

It can be concluded that TBLT is certainly beneficial to the EFL students. However, in order that students have opportunities to experience samples of meaning-focused language use, they must be given chances to try out language and to make the best use of what they know in various real-life situations (Ellis, 2003); and teachers should know different types of tasks. Regarding task-based speaking activities, researchers have identified different types such as interviews through the use of questions and answers, information gaps, role play, matching activities, exchanging information, picture description and picture stories, discussion and decisions, and problem solving (Prabhu, 1987; Clark, 1987; Pattison, 1987; Pica \& Doughty, 2008; Crookall \& Oxford, 1991)

So far researchers have investigated different aspects related to TBLT. For example: implementation of TBLT (Carless, 2001; Muller, 2005); effect of TBLT (Birjandi \& Ahangari, 2008); TBLT in teaching of grammar (Nguyen, 2007); tasks used to teach speaking skill (Tran, 2011); TBLL and student motivation in vocabulary acquisition (Le \& Nguyen, 2012); tasks in classrooms (Nguyen, 2013): factors affecting TBLT (Le, 2014); challenges of shifting to TBLT (Phượng, 2016); teachers' perceptions towards the implementation of TBLT (Tran \& Nguyen, 2018), and many others both in the international and Vietnamese contexts.

Although issues concerning teachers' and students' attitudes and perceptions towards TBLT have received a great interest from educational researchers, almost no studies have been conducted at PUH to deal with the application of TBSAs in improving non-English majored students' speaking skills. This study, therefore, aims to investigate EFL teachers' and students' perceptions of TBSAs for nonEnglish majored students in EFL classrooms at PUH. More specifically, this study was conducted in an attempt a) to discover the extent to which EFL teachers understand TBLT principles; b) to find out what types of TBSAs are often used in EFL classes; and c) to explore the teachers' and students' perceptions of the advantages of TBSAs in EFL classes. The study attempted to address the following three research questions.

- How do EFL teachers perceive TBLT principles?

- What types of task-based speaking activities are often used in EFL classes?

International Journal on Studies in English Language and Literature (IJSELL) 

Level

- What are the EFL teachers' and students' perceptions of the advantages of task-based speaking activities used in EFL classes?

\section{RESEARCH METHODS}

\subsection{Participants}

The study was conducted at PUH in Ho Chi Minh City-Vietnam with the participation of two main groups of sample. The total number of participants of the study was 383 non-English majored students and 10 English teachers. Regarding student participants, the non-English majored students from 20 classes of second, third, and fourth academic years of 9 faculties including Korean Studies, Japanese Studies, Business Administration, Tourism Management, Finance and Banking, Information Technology, Industry of Food, Arts Design, Electronic Engineering participated in the study. These classes studied the same English textbook entitled "American Headway" for the English subject and had equal number of English classes weekly. 222 of them are male and 161 are female. Their ages range from 19 to 23. Regarding teacher participants, 10 teachers were selected as the second group of the sample for the study. They all have MA degrees in TESOL and more than 3 years of teaching experience. 7 of them are male and 3 are female. Their ages range from 25 to 41 .

\subsection{Research Instruments}

The study employed two major instruments for collecting both quantitative and qualitative data, namely the questionnaire and observation. The student questionnaire consisted of two parts; part one asked about the demographic information of the participants and part two consisted of 9 items asking about students' perceptions of TBSA designed in the textbook and 17 items asking about the advantages of TBSA consisting of three categories, namely improvement of interaction, improvement of confidence and motivation, and improvement of language skills and knowledge. The teacher questionnaire consisted of three parts; part one asked about the demographic information of the participants; part two consisted of 11 items adapted from Liu, Mishan and Chambers (2018) asking about the teachers' perceptions of TBLT principles; and part three consisted of 9 items asking about teachers' perceptions of the TBSAs designed in the textbook and 17 items asking about the advantages of the task-based speaking activities. All of the items of the questionnaires were specially designed according to 5-point Likert scale ranging from 1 (Strongly Disagree); 2 (Disagree); 3 (Undecided); 4 (Agree); 5 (Strongly Agree); and for the students, the questionnaire items were translated into Vietnamese.

Regarding the observations, the main purpose of observation in this study is to verify the ways the teachers applied TBLT principles in teaching speaking activities and whether the types of TBSAs were implemented in EFL classes.

\subsection{Data Collection and Analysis Procedures}

The data collection for the study was carried out from December 2018 to March 2019. The questionnaires and classroom observations were conducted in PUH campus. In order to access to the participants to collect the data, the researcher had an initial meeting with the teachers for discussing the purposes of the research. To conduct the student questionnaire survey, the researcher contacted the monitor in each class who then helped the researcher delivered and collected the questionnaires. 420 questionnaire copies were administered to the students of 9 faculties, but 413 copies were returned and 383 copies were correctly and validly completed (92\%). To conduct the teacher questionnaire, the researcher met them during the time they had break so that their classes were not interrupted.

For classroom observations, after getting permission of the teachers, the researcher arranged the time for observations with due consideration of their convenience. 5 classes from different disciplines were selected for non-participant observations, and each observation lasted 45 minutes. During the time of observations, a checklist was used for the class observation in accordance with the purposes of the study (Patton, 2002), and note-taking technique was employed during observations. All of the observations focused on the teaching of speaking skills, especially on what task-based speaking activities were implemented, how the tasks were organized, what attitudes the students had towards the tasks, what the teachers did during the implementation of the activities. Based on the principles of TBLT, all might help the researcher be able to reflect the teachers' understanding of TBLT and how they applied theory in the implementation of the task-based speaking activities. 

Level

Regarding data analysis procedures, for analyzing quantitative data collected from the questionnaires, descriptive statistics was employed through the use of SPSS version 22. Percentages, mean scores and standard deviation were calculated. For qualitative data collected from observations, "content analysis" was employed. It can be explained that the notes taken from the observation were categorized into the themes in order to record the ways the teacher implemented TBSA. The responses were then written in narrative; the observed classes were coded as CL1; CL2; CL3; CL4; CL5; and extracts from class observation excerpts were presented.

Regarding reliability and validity of the study, the questionnaire was piloted. It was done in 6 different classes with 10 students from each class. Cronbach's Alpha indexes were calculated. The results were .724 for 11 items used to measure teachers' understanding of TBLT and .842 for 17 items used to measure teachers' and students' perceptions of the advantages of TBSAs. It can be seen that the rate is rather high.

\section{RESULTS AND DISCUSSION}

\subsection{Teachers' Understanding of TBLT}

Data displayed in Table 1 shows that most of the teachers understand about TBLT principles rather well $(\mathrm{M}>3.60)$. Obtaining the highest agreement of the teachers is that a task motivates the students to be engaged in the target language use (item 9) with $\mathrm{M}=4.50$; and nearly all of the teachers agreed that TBLT is based on student-centered instructional approach (item 2), is a communicative goal direct (item 4), and that material used with TBLT should be based on the real-life contexts (item 10) and that a task is activity in which the target language is used by the students (item 7); and a task involves students in comprehending, manipulating, producing, and interacting with the target language (item 8) with $\mathrm{M}=4.10,4.10,4.10,4.20$ and 4.20 respectively.

What is more, it is evident that most of the teachers agreed about the remaining characteristics of TBLT, including TBLT offers an opportunity for natural learning to occur inside the classroom (item 1) with $M=3.80$; and the same number of teachers thought that it is necessary to apply three stages: pre-task, task implementation, and post-task whenever a task is carried out (item 3) with $\mathrm{M}=3.80$, and a task in TBLT involves primary focus on meaning (item 5) with $\mathrm{M}=3.80$. About three-fourth of the teacher thought that a task has a clear defined outcome (item 6) with $\mathrm{M}=3.70$, and Language use in classroom tasks should be restricted to L2 only (item 11) with $\mathrm{M}=3.60$. It is evident that all of the 11 statements mentioned in Table 1 proved that most of the EFL teachers who teach English to nonEnglish majored students at PUH understanding TBLT principles.

Regarding data collected from the classroom observations, the findings revealed that among five TBSAs carried out in the five classes, one speaking task was rather successfully carried out in CL1 and the implementation of the other four speaking tasks still showed some shortcomings. Several excerpts illustrated what happened in the observed classes are described as follows:

For example, the TBSA "Talking about changes in the environment" in unit 5, American Headway Book 3 was carried out in CL1. Based on TBLT theory, this task is considered as "talking about a real-life topic". It was observed that the teacher carried out three stages of a task. First the teacher showed the objectives of the task clearly, and the she organized the class. She got the students sit in pairs and gave instructions. She asked the students to look at the pictures and answered some questions. Then the students worked in pairs, asked and answered the questions. After that, she asked several students to answer the questions. Students were asked to work in groups of four. While the students were discussing the question, the teacher moved around the class, giving some more instructions in both L2 and L1 for students who did not understand how to do the task. She tried to motivate the students. After the task, the teacher asked each group to express their opinions. The students worked in pairs and groups excitingly; After all, she corrected errors for the students who did not speak correctly (Observation excerpt CL1, 18/12/2018).

It is evident that the teacher in CL1 was rather successful in the implementation of a TBSA. Because he had a clear understanding about how to carry out a task-based speaking activity, as a result, the students were interested in the performance of the task. Communication in English really took place in CL1.

The TBSA "Role play: Making arrangements to meet" on page 42 in Unit 5 American Headway Book 3 was another type of speaking tasks which was carried out in CL2. The teacher did not identify 

Level

objectives of the task for the students. He asked the students to work in pair. During the task, teacher moved around the class, giving instructions in Vietnamese to students. After the task, the teacher called the students to volunteer to play the role, but as observed only one pair did the task (Observation excerpt CL2, 20/12/2018).

Another TBSA was carried out in CL3. As observed, several shortcomings were noted. The speaking task was carried out in CL3 was "Exchanging information about a story: Rocket man" in Unit 5 American Headway Book 3. The teacher just organized the students in pair work. He specified the purpose of the task and gave clearly instructions and examples. During the task, the teacher almost did not move. However, as observed only about $60 \%$ of the students were active and really paid attention to the task. The others did nothing or only talked in Vietnamese. The task took about 15 minutes (Observation excerpt CL3, 21/12/2018).

In one more class observation, the findings revealed that the TBSA was not very effectively carried out. The speaking task was "Playing the role of a reporter, the other one plays the role of Tony Wheeler in Unit 1 American Headway Book 4. It was observed that before asking the students to work in pair, the teacher did not show the students the objectives of the task. He did not give instructions or examples. During the task, the teacher moved regularly, prompting students to use English. After the task, the teacher asked the students to play the role again. Ten pairs were called. It was observed that most of the students were excited. However, no corrections were made although many students made mistakes in their performance (Observation excerpt CL4, 28/2/2019).

The last speaking task was "Telling a story" in Unit 1 Book 4 American Headway Book three. As observed the teacher did not tell the students about the purposes of the task, but she gave instruction. She said, "work in pair read the story and then tell the story to your friend". However, she did not tell the students how to read, what information to get and how to retell the story. The students were not aware of what to do. After the task, the teacher asked 4 students to retell the story. As observed not many students could do this task. It might be that they did not understand the whole story, or they might not know how to retell the story (Observation excerpt CL5, 1/3/2019).

Table1. Descriptive statistics of teachers' understanding of TBLT

\begin{tabular}{|c|c|c|c|c|}
\hline No & Statements & $\mathbf{N}$ & $\mathbf{M}$ & St. D \\
\hline 1 & TBLT offers an opportunity for natural learning to occur inside the classroom. & 10 & 3.80 & .632 \\
\hline 2 & TBLT is based on student-centered instructional approach & 10 & 4.10 & .737 \\
\hline 3 & TBLT includes three stages: pre-task, task implementation, and post-task & 10 & 4.00 & .816 \\
\hline 4 & A task is a communicative goal direct. & 10 & 4.10 & .567 \\
\hline 5 & A task involves primary focus on meaning. & 10 & 3.80 & .788 \\
\hline 6 & A task has a clear defined outcome. & 10 & 3.70 & .674 \\
\hline 7 & A task is an activity in which the target language is used by the students. & 10 & 4.20 & .788 \\
\hline 8 & $\begin{array}{l}\text { A task involves students in comprehending, manipulating, producing, and } \\
\text { interacting with the target language. }\end{array}$ & 10 & 4.20 & .788 \\
\hline 9 & A task motivates the students to be engaged in the target language use. & 10 & 4.50 & .527 \\
\hline 10 & Material used with TBLT should be based on the real-life contexts & 10 & 4.10 & .737 \\
\hline 11 & Language use in classroom tasks should be restricted to L2 only. & 10 & 3.60 & .699 \\
\hline
\end{tabular}

The findings of the study revealed that most of the teachers had good understanding of TBLT principles. However, not all the tasks were successfully carried out in the five EFL classes. Despite their clear understanding of TBLT principles, it does not mean that they could apply TBLT in their classes effectively. That is because many factors may negatively affect their instruction. The teachers must really understand that in order to be effective in the application of TBLT, it is necessary for them not only to understand TBLT principles, but they themselves must often practice using this approach in their classes. They should also understand their students' different learning styles and preferences. It can also be said that not all the tasks designed in the textbook are relevant for students in non-native English speaking contexts like Vietnam. The teachers were observed not to make any modifications or changes so that the tasks may fit the non-English majored students' proficiency level. Although the finding of the study was consistent with that of Jeon and Hahn's study (2006) that found that EFL teachers in Asian contexts have good understanding of TBLT principles, it is undeniable that theory and practice have a long distance. EFL teachers need to be careful in the implementation of TBLT in EFL education. 

Level

\subsection{Types of Task-Based Speaking Activities Used in EFL Classes}

All the TBSAs in the textbook were selected and sorted out. The total TBSAs which were sorted out was 9 (See Table 2). They were put in a list and both the teacher and student participants were asked to identify which TBSAs were often used for teaching speaking skills in the classroom. Interestingly, most of the teachers and students agreed that those TBSAs were implemented in their classes.

Table2. Descriptive statistics of the use of TBSAs

\begin{tabular}{|l|l|l|l|l|l|}
\hline No. & \multicolumn{1}{|c|}{ Task-based speaking activities } & \multicolumn{2}{|c|}{$\mathbf{N}$ (teachers) $=\mathbf{1 0}$ (students) $\mathbf{3 8 3}$} \\
\cline { 3 - 6 } & & $\mathbf{n}$ & $\mathbf{\%}$ & \multicolumn{1}{|c|}{$\mathbf{n}$} & $\mathbf{\%}$ \\
\hline 1 & A class survey: Finding information about someone or something & 7 & $70 \%$ & 208 & $54.3 \%$ \\
\hline 2 & Comparing and swapping information about two things or people & 9 & $90 \%$ & 207 & $54.0 \%$ \\
\hline 3 & Giving opinions about something & 9 & $90 \%$ & 243 & $63.4 \%$ \\
\hline 4 & Discussing a list of something & 7 & $70 \%$ & 256 & $66.8 \%$ \\
\hline 5 & Playing the role of someone in a conversation & 9 & $90 \%$ & 208 & $54,3 \%$ \\
\hline 6 & Interviewing someone about something & 9 & $90 \%$ & 176 & $46.0 \%$ \\
\hline 7 & Exchanging information about something & 7 & $70 \%$ & 312 & $81.4 \%$ \\
\hline 8 & Retelling stories & 3 & $30 \%$ & 233 & $60.8 \%$ \\
\hline 9 & Talking about a real-life topic & 8 & $80 \%$ & 276 & $72.0 \%$ \\
\hline
\end{tabular}

\subsection{Teachers' Perceptions of Use of Types of Task-based Speaking Activities}

Data displayed in Table 2 shows that all the 9 TBSAs were carried out in classes for non-English majored students. Accordingly, 9 teachers (90\%) agreed that such tasks as "Comparing and swapping information about two things", "Giving opinions about something", "Playing the role of someone in a conversation", and "Interviewing someone about something" were often applied in the development of non-English majored students' speaking skills. It is evident that these tasks are really useful and more interesting to students. In addition, 8 teachers $(80 \%)$ agreed that "Talking about a real-life topic" was also used for the students in EFL classes. Having a lower frequency (70\% of the teachers) are the three TBSA "A class survey - Finding information about someone", "Discussing a list of something" and "Exchanging information about something"; and the lowest frequency (30\% of the teachers) is speaking task 8 "Retelling stories". It may be that this task is not very popular with the students, and it may be not easy to carry out in a large-size class with about 50 students.

\subsection{Students' Perceptions of the Use of Types of Task-based Speaking Activities}

Data displayed in Table 2 shows that all the 9 TBSAs were carried out in classes for non-English majored students. Accordingly, among 383 students, 208 students (54.3\%) agreed that "A class survey - Finding information about someone" was often used to develop students' speaking skills, 207 students (54\%) students agreed that "Comparing and swapping information about two things" task was also carried out in class. Obtaining a higher rate is "Giving opinions about something" task with the agreement of 243 students (63.4\%). More interesting, many students agreed that "Discussing a list of something" task was often organized for them to practice speaking skills with the agreement of 256 students $(66.8 \%)$. Meanwhile, only about half of the students agreed that "Playing the role of someone in a conversation" and "Interviewing someone about something" tasks were performed in their English classes with the agreement of 208 (54.3\%) and $176(46 \%)$ respectively. The task "Exchanging information about something" obtained the highest agreement among the students (81.4\%). It may be because students often worked in pair to ask each other about something in their classes. The last two tasks "Retelling stories" and "Talking about a real-life topic" obtained the agreement of nearly threefourths of the students with the percentages $60.8 \%$ and $72.0 \%$ respectively.

In conclusion, although there are some differences between the teachers' and students' perceptions of the TBSAs used in their EFL classes, it is evident that all of the 9 types of TBSAs designed in the textbook were implemented to enhance the students' speaking skills. It can also be affirmed that different teachers teaching different classes implemented different types of activities in their classes. That may be because of the students' preferences and proficiency.

In addition, the purpose of classroom observations was to find out whether the teachers carried out TBSAs in their classes. Data from class observations (see Table 3) also revealed that the TBSA which are designed in the textbook were implemented in the EFL classes at PUH. It may be said that the 

Level

teachers did not neglect teaching speaking skills to their students. This finding is consistent with the teachers and students' perceptions of the types of the TBSA carried out in their classes. Table 3 shows the five TBSAs which were organized for EFL students to develop speaking skills.

Table3. TBSAs implemented in EFL classes

\begin{tabular}{|c|c|c|c|c|}
\hline No & Classes & Date & Task-based Speaking Activities & Unit \\
\hline 1 & CL1 & $\begin{array}{l}18 \text { Dec } \\
2018\end{array}$ & Talking about a real-life topic & $\begin{array}{l}\text { Book } 3 \text { - Unit 5: Our changing world - } \\
\text { Things our grandchildren may never see }\end{array}$ \\
\hline 2 & CL2 & $\begin{array}{l}20 \mathrm{Dec} \\
2018\end{array}$ & $\begin{array}{l}\text { Interviewing someone about } \\
\text { something }\end{array}$ & $\begin{array}{l}\text { Book } 3 \text { - Unit 5: Our changing world - } \\
\text { Things our grandchildren may never see }\end{array}$ \\
\hline 3 & CL3 & $\begin{array}{l}21 \mathrm{Dec} \\
2018\end{array}$ & $\begin{array}{l}\text { Exchanging information about } \\
\text { something: }\end{array}$ & $\begin{array}{l}\text { Book } 3 \text { - Unit 5: Our changing world - } \\
\text { Rocket man }\end{array}$ \\
\hline 4 & CL4 & $\begin{array}{l}28 \text { Feb } \\
2019\end{array}$ & $\begin{array}{l}\text { Playing the role of someone in a } \\
\text { conversation }\end{array}$ & $\begin{array}{l}\text { Book } 4 \text { - Unit 1: No place like home - } \\
\text { Interview }\end{array}$ \\
\hline 5 & CL5 & $\begin{array}{l}\text { 01 Mar } \\
2019\end{array}$ & Retelling stories & $\begin{array}{l}\text { Book } 4 \text { - Unit } 1 \text { - No place like home - } \\
\text { Paradise lost }\end{array}$ \\
\hline
\end{tabular}

The findings of the study showed that over half of the students and most of the teachers agreed that more or less TBSAs in the textbooks were implemented in EFL classes at the context. Although not all the types of TBSAs were implemented in all classes, it is evident that EFL teachers have tried their best to develop students' speaking skills. They did not choose all tasks for their classes; that might be because insufficient time allotment for the English; or they might have to cover many other tasks in the textbook to meet the requirements of the course syllabus. Nonetheless, the teachers could recognize that TBSA are considered purposeful activities that emphasize communication and meaning. Students learn English by interacting communicatively and purposefully while engaged in meaningful activities (Shehadeh, 2005). TBSAs were implemented in EFL classes at PUH also implied that most of them held positive attitudes towards the practice of TBLT in their classrooms. To some extent, the findings could imply that these teachers might be willing to try out TBLT in their instruction.

\subsection{The Advantages of Task-Based Speaking Activities}

\subsubsection{Teachers' Perceptions of the Advantages of Task-Based Speaking Activities}

\section{a) Enhancement of Interaction}

Data displayed in Table 4 below shows that most of the teachers agreed that speaking tasks really enhance students' interaction in an EFL class. It is evident that TBSA require students to work in pairs and groups (item 1) with $\mathrm{M}=4.50$. Pair work and group work are considered as one of the best ways for the students to increase their interaction with their classmates. When working together, the students have to find out ways to solve a problem or deal with some work. They have to negotiate with each other to reach an agreement so they can increase cooperative relationships with each other when doing tasks (item 12) with $\mathrm{M}=4.30$; and they not only work with their classmates, but they also have to interact with their teachers, for example, sometimes they ask for clarification of some new words. That is why tasks increase student-teacher interaction (item 15) with $\mathrm{M}=3.80$.

Table4. TBSAs for enhancement of interaction for students

\begin{tabular}{|l|l|l|l|l|}
\hline No & Items & N & M & St.D \\
\hline 1 & The tasks of speaking require students to work in pairs and groups. & 10 & 4.50 & .527 \\
\hline 12 & $\begin{array}{l}\text { The students can increase cooperative relationships with each other when } \\
\text { doing the tasks. }\end{array}$ & 10 & 4.30 & .483 \\
\hline 15 & The tasks increase student-teacher interaction. & 10 & 3.80 & .788 \\
\hline
\end{tabular}

\section{b) Enhancement of Language Skills and Knowledge}

Data displayed in Table 5 below shows that most of the teachers agreed that speaking tasks enhanced students' language skills and knowledge. The mean scores are very high $(\mathrm{M}>3.90)$. According to the teachers, TBSAs assist EFL students with their learning speaking skill as well as other skills. More specifically, tasks help to improve students' speaking skill a lot (item 3) with $\mathrm{M}=3.90$, provide reallife situations for the students to practice speaking (item 11) with $M=4.40$, and develop other skills such as reading and listening because the students have to read and listen before speaking (item 14) with $M=4.10$. The teachers also thought that TBSA enhanced their students' language knowledge with 

Level

a high level of agreement. Most of the teachers agreed that tasks helped the students to apply grammar and vocabulary in speaking (item 9) with $M=4.0$, improve pronunciation (item 10) with $M=4.10$, and use the target language more often (item 13) with $\mathrm{M}=4.20$.

Table5. TBSAs for enhancement of language skills and knowledge

\begin{tabular}{|l|l|l|l|l|}
\hline No & \multicolumn{1}{|c|}{ Items } & N & \multicolumn{1}{|c|}{ M } & St.D \\
\hline 3 & The tasks help the students to improve speaking skill a lot. & 10 & 3.90 & .567 \\
\hline 9 & The tasks help the students to apply grammar and vocabulary in speaking. & 10 & 4.00 & .816 \\
\hline 10 & The tasks help the students to improve pronunciation. & 10 & 4.10 & .737 \\
\hline 11 & The tasks provide real-life situations for the students to practice speaking. & 10 & 4.40 & .699 \\
\hline 13 & The tasks help the students to use the target language (English) more often. & 10 & 4.20 & .788 \\
\hline 14 & $\begin{array}{l}\text { The tasks help the students develop other skills such as reading and listening } \\
\text { because the students have to read and listen before speaking. }\end{array}$ & 10 & 4.10 & .737 \\
\hline
\end{tabular}

c) Improvement of Confidence and Motivation

Data displayed in Table 6 below shows that most of the teachers agreed that TBSAs enhanced students' confidence and motivation. In the teachers' opinion, 9 tasks designed in textbook are really interesting to the students (item 2) with $\mathrm{M}=3.8$, and make the students get confident and motivated gradually (item 4) with $\mathrm{M}=4.20$. Tasks also require the students to prepare lessons at home (item 5) with $\mathrm{M}=3.70$, which means they get more and more autonomous in their learning. The more autonomous they are, the more confident they get. What is more, most of the teachers agreed that when preparing for those activities, the students may get more fun (item 6) with $\mathrm{M}=3.80$ ). It is undeniable that tasks require the students to participate actively in speaking tasks (item 7). That is why most of the teacher agreed about this aspect with $M=3.90$. Similarly, a similar number of the teachers agreed that tasks enabled the students to improve their imagination and creativity (item 8), help the students to make decisions about topics on their own (item 16) and provide a relaxing English learning atmosphere (item 17) with $\mathrm{M}=3.90,4.10,3.80$ and 4.20 respectively. In foreign language learning, a relaxing atmosphere is really important. It helps students to be more active and creative in their learning. They may decide what to do by themselves in order to increase their knowledge and skills.

Table6. TBSAs for enhancement of students' confidence and motivation

\begin{tabular}{|l|l|l|l|l|}
\hline No & \multicolumn{1}{|c|}{ Items } & N & \multicolumn{1}{|c|}{ M } & \multicolumn{1}{|c|}{ St. D } \\
\hline 2 & The tasks are really interesting to the students. & 10 & 3.80 & 1.032 \\
\hline 4 & The tasks make the students get confident and motivated gradually. & 10 & 4.20 & .788 \\
\hline 5 & The tasks require the students to prepare lessons at home. & 10 & 3.70 & 1.059 \\
\hline 6 & It is really fun for the students to prepare for those tasks. & 10 & 3.80 & 1.229 \\
\hline 7 & The tasks require the students to participate actively in speaking activities. & 10 & 3.90 & .875 \\
\hline 8 & The tasks enable the students to improve imagination and creativity. & 10 & 4.10 & .875 \\
\hline 16 & The tasks help the students to make decisions about topics on their own. & 10 & 3.80 & .788 \\
\hline 17 & The tasks provide a relaxing English learning atmosphere. & 10 & 4.20 & .788 \\
\hline
\end{tabular}

In conclusion, data of the questionnaire revealed that most of the teachers agreed that the TBSA designed in the textbook were really helpful to their students. These tasks not only could enhance the students' language skills and knowledge, but they also supported in the development of interaction, confidence and motivation.

\subsubsection{Students' Perceptions of the Advantages of Task-based Speaking Activities}

\section{a) Enhancement of Interaction between Students}

Data displayed in Table 7 below shows that most of the students perceived that TBSAs really their interaction in an EFL class. Most of them agreed that speaking tasks require them to work in pairs and groups (item 1) with $\mathrm{M}=4.13$. Obviously, they thought that pair work and group work could help them increase their interaction with their classmates, and that they should work in pairs or groups so that they might increase their speaking ability. Moreover, about three-fourths of the students thought that they could increase cooperative relationships with each other when doing tasks (item 12) with $\mathrm{M}=3.83$; a similar number of the students perceived that tasks increase student-teacher interaction (item 15) with $\mathrm{M}=3.98$. These findings are consistent with the teachers' perceptions. That is to say, most of the students and teachers had similar perceptions about the three advantages of TBSAs. 
Task-based Language Teaching: Task-based Speaking Activities Used in EFL Classrooms at Tertiary Level

Table7. TBSAs for enhancement of interaction for students

\begin{tabular}{|l|l|l|l|l|}
\hline No & Items & N & M & St.D \\
\hline 1 & The tasks of speaking require students to work in pairs and groups. & 383 & 4.13 & .689 \\
\hline 12 & $\begin{array}{l}\text { The students can increase cooperative relationships with each other when } \\
\text { doing those tasks. }\end{array}$ & 383 & 3.83 & .824 \\
\hline 15 & The tasks increase student-teacher interaction. & 383 & 3.98 & .721 \\
\hline
\end{tabular}

\section{b) Enhancement of Language Skills and Knowledge}

It can be seen in Table 8 below shows that about three-fourths of the students agreed that TBSAs could enhance their language skills and knowledge. The mean scores are 3.80. According to the students, TBSAs could help them in their learning speaking skill and developing other skills. Regarding language skills, tasks help to improve speaking skill a lot (item 3) with $M=3.937$, provide real-life situations for the students to practice speaking (item 11) with $M=3.75$, and develop other skills such as reading and listening because the students have to read and listen before speaking (item 14) with $M=3.94$. A similar number of the students also agreed that TBSAs enhanced their language knowledge. More specifically, tasks could help them to apply grammar and vocabulary in speaking (item 9) with 3.97, improve pronunciation (item 10) with $M=3.93$, and use the target language more often (item 13) with $\mathrm{M}=3.84$.

Table8. TBSAs for enhancement of language skills and knowledge

\begin{tabular}{|l|l|c|l|l|}
\hline No & \multicolumn{1}{|c|}{ Items } & N & M & St.D \\
\hline 3 & The tasks help the students to improve speaking skill a lot. & 383 & 3.93 & .866 \\
\hline 9 & The tasks help the students to apply grammar and vocabulary in speaking. & 383 & 3.97 & .779 \\
\hline 10 & The tasks help the students to improve pronunciation. & 383 & 3.93 & .806 \\
\hline 11 & The tasks provide real-life situations for the students to practice speaking. & 383 & 3.75 & .831 \\
\hline 13 & The tasks help the students to use the target language (English) more often. & 383 & 3.84 & .839 \\
\hline 14 & $\begin{array}{l}\text { The tasks help the students develop other skills such as reading and listening } \\
\text { because the students have to read and listen before speaking. }\end{array}$ & 383 & 3.94 & .790 \\
\hline
\end{tabular}

\section{c) Enhancement of Students' Confidence and Motivation}

Data displayed in Table 9 below illustrates that about three-fourths of the students agreed that TBSAs enhanced their confidence and motivation. Those students thought the 9 tasks designed in the textbook are really interesting to the students (item 2) with $\mathrm{M}=3.78$, and make them become confident and motivated in learning English (item 4) with $M=3.88$. They also perceived that the designed tasks also required them to prepare lessons at home (item 5) with $M=3.74$. It seems that with those students, doing homework and preparing for lessons in advance may help them get more confident in class. However, only about half of the students agreed that when preparing for those tasks, they may get more fun (item 6) with $\mathrm{M}=3.58$. It is undeniable that according to about three-fourths of them, the tasks required them to participate actively in speaking tasks (item 7) with $M=3.84$. Similarly, a similar number of the students agreed that tasks enabled them to improve their imagination and creativity (item 8), help them to make decisions about topics on their own (item 16) and provide a relaxing English learning atmosphere (item 17) with $\mathrm{M}=3.74$, 3.51, and 3.91respectively. In foreign language learning, a relaxing atmosphere is really important. It helps students to be more active and creative. They may decide what to do themselves in order to increase their knowledge and skills.

Table9. TBSAs for enhancement of students' confidence and motivation

\begin{tabular}{|l|l|c|c|c|}
\hline No & \multicolumn{1}{|c|}{ Items } & N & M & St.D \\
\hline 2 & The tasks are really interesting to the students. & 383 & 3.78 & .779 \\
\hline 4 & The tasks require the students to participate actively in speaking activities. & 383 & 3.84 & .760 \\
\hline 5 & The tasks make the students get confident and motivated gradually. & 383 & 3.88 & .829 \\
\hline 6 & The tasks require the students to prepare lessons at home. & 383 & 3.74 & .834 \\
\hline 7 & It is really fun for the students to prepare for those tasks. & 383 & 3.58 & .866 \\
\hline 8 & The tasks enable the students to improve imagination and creativity. & 383 & 3.74 & .816 \\
\hline 16 & The tasks help the students to make decisions about topics on their own. & 383 & 3.51 & .852 \\
\hline 17 & The tasks provide a relaxing English learning atmosphere. & 383 & 3.91 & .867 \\
\hline
\end{tabular}

International Journal on Studies in English Language and Literature (IJSELL) 

Level

The findings of the study also revealed that most of the teachers and about three-fourths of the students perceived that TBSAs have a lot of advantages. One of the advantages which received high agreement from both teachers and students is that TBSAs require students to work in pairs and groups. It is evident that during EFL classes, pair work and group work have been organized for the students to practice and develop speaking skills; and the students might recognize that they get benefits from this method of learning. This finding is consistent with that of Sarıçoban and Karakurt's study (2016) that found that students preferred working in groups or pairs during the implementation of TBLAs. Other advantages which had high agreement of both teachers and students are "TBSAs provide real-life situations for the students to practice speaking, help them to use the target language more often, make them get confident and motivated, and provide a relaxing English learning atmosphere." It is really interesting to note that teachers recognize that TBSAs provide many advantages in teaching EFL because they offer language experience in the classroom, enhance interaction among students in class, improve students' communicative competency and provide students with more opportunities to use English (Nunan, 2004). The findings of the study are in alignment with those of the studies conducted by (Widia \& Astawa, 2014; Sarıçoban \& Karakurt, 2016) that found that TBSAs made students enjoy learning English; they were more motivated and thought that tasks are a good way to improve English speaking skills. Anyhow, it can be concluded that TBLT has been beneficial for many non-English majored students PUH. Their English proficiency has gradually increased partly thanks to their motivation and the teachers'understanding and application of TBLT in the context.

\section{CONCLUSION AND RECOMMENDATIONS}

This study aims to explore teachers' and students' perceptions of TBSA used in EFL classes at PUH. Through the use of the questionnaires and observations as the main research instruments, it can be proved most of the teachers had good understanding of TBLT principles; almost all types of TBSAs were implemented in EFL classes; and most of the teachers and students perceived that TBSAs have various advantages in developing students' speaking skills. However, classroom observations have verified that the implementation of TBSAs in EFL classes still have shortcomings and difficulties. Several teachers are still subjective in their instruction. They may think that they can apply TBLT well in their workplace; and many students still do not recognize the importance of learning English; and they are not autonomous in their learning. That is why the study suggests that for teachers who teach English to non-English majored students, studying more about the principles of TBLT is essential, especially they should discover how a TBSA may be effectively carried out in an EFL classes for non-English majored students. They should be able to use the target language fluently and appropriately. When giving instructions to the students in the target language, teachers should use simple target language so that the students gradually acquire the skills. Managing a language classroom is always considered as an art. To be able to get all the students in the class involved in the activity is also a requirement that any EFL teacher has to meet. Only by doing so, can TBSAs be successfully in the context; and for non-English majored students, being aware of the advantages of TBSAs is not sufficient. In the classroom, they should be more active in their learning. Teachers can only help when students are motivated and really want to learn. Participating actively in TBSAs will certainly bring a lot of benefits to students. It is suggested that students should be autonomous, take risks and be confident in EFL learning.

\section{REFERENCES}

[1] Birjandi, P. \& Ahangari, S. (2008). Effects of task repetition on the fluency, complexity and accuracy of Iranian EFL learners of oral discourse. The Asian EFL Journal, 10 (3) 28-52.

[2] Breen, M. P. (1987). Learner contribution to task design. New York: Prentice Hall.

[3] Burns. A. \& Joyce, H. (1997). Focus on speaking. Sydney: National Center for English Language Teaching and Research.

[4] Carless, D. V. (2001). Factors in the implementation of task-based teaching in primary school. Hong Kong: English department, Hong Kong Institute for Education.

[5] Clark, J. (1987). Curriculum renewal in school foreign language learning: Oxford: Oxford University Press. 
[6] Crookall, D. \& Oxford, R.L. (1991). Dealing with anxiety: some practical activities for language learner and teacher trainees. In E.K. Horwitz \& D.J. Young (Eds.). Language Anxiety: From Theory and Research to Classroom Implications (pp.141-50). Englewood Cliffs, NJ: Prentice Hall.

[7] Ellis, R. (2003). Task-based language learning and teaching. Oxford: Oxford University Press.

[8] Jeon, I. J. \& Hahn, J. W. (2006). Exploring EFL teachers' perceptions of task-based language teaching: A case study of Korean secondary school classroom practice. Asian EFL Journal, 8, 123-139.

[9] Lee, J. F. (2000). Tasks and communicating in language classrooms. Boston: McGraw-Hill.

[10] Le, Ngoc Thanh \& Nguyen Buu Huan (2012). Task-based language learning and student motivation in vocabulary acquisition. Language Education in Asia, 3 (1), 106-120.

[11] Le, Van Tuyen (2014). Factors affecting task-based language teaching from teachers' perspective, Study in English Language Teaching, 2 (1), 108-122.

[12] Liu, Y., Mishan, F. \& Chambers, A. (2018): Investigating EFL teachers' perceptions of task-based language teaching in higher education in China, The Language Learning Journal, DOI: 10.1080/09571736.2018.1465110.

[13] Muller, T. (2005). Adding tasks to textbooks for beginner learners. Cambridge: Cambridge University Press.

[14] Nation, I. S. P. \& Newton, J. (2009). Teaching ESL/EFL listening and speaking. New York: Routledge.

[15] Nguyen, Buu Huan (2013). Beliefs about support for teacher change in English for Specific Purposes university classes. New Zealand Studies in Applied Linguistics, 19 (2), 36-48.

[16] Nguyen, Phuong Y Nhi. (2007) How to teach grammar communicatively to children at Vietnam USA society English training service center.(Unpublished MA Thesis). Ho Chi Minh City: University of Social Sciences and Humanities.

[17] Norris, J., Hudson, B., \& Bonk, W. (2002). Examinee abilities and task difficulty in task-based second language performance assessment. Language Testing, 19, 395-418.

[18] Nunan, D. (2004). Designing tasks for the communicative classroom. Cambridge: Cambridge University Press.

[19] Patton, M. (2002). Qualitative research and evaluation methods and evaluation methods (3rd ed.). Thousand Oaks, Calif.: Sage Publications.

[20] Pattison, P. (1987). Developing communicative skills. Cambridge: Cambridge University Press.

[21] Pica, T., \& Doughty, C. (2008). The role of group work in classroom second language acquisition. Studies Second Language Acquisition, 7, 233-248.

[22] Phuong, Hoang Yen (2016). Challenges of shifting to task-based language teaching: A story from a Vietnamese teacher. Can Tho University Journal of Science, 2, 37-45.

[23] Prabhu, N. S. (1987). Second language pedagogy. Oxford: Oxford University Press.

[24] Richards, J. \& Rodgers, T. (2001). Approaches and methods in language teaching. (2nd ed.). Cambridge: Cambridge University Press.

[25] Sarıçoban, A. \& Karakurt, L. (2016). The use of task-based activities to improve listening and speaking skills in EFL context. Sino-US English Teaching, 13 (6), 445-459.

[26] Shehadeh, A. (2005). Task-based language learning and teaching: Theories and applications. In C. Edwards and J. Willis (Eds.). Teachers exploring tasks in English language teaching. New York: Macmilan.

[27] Thornbury, S. (2007). Certificate in English language teaching to adults. Cambridge: Cambridge University Press.

[28] Tran, Thi Thanh Truc. (2011). Designing communicative tasks to teach speaking skills for first-year students of associate program in English at USSH. (Unpublished MA Thesis). University of Social Sciences and Humanities. Vietnam.

[29] Tran, Trung Nghia \& Nguyen, Buu Huan (2018). Teachers' perceptions about task-based language teaching and its implementation. European Journal of Foreign Language Teaching, 3 (2), 2537 - 1754. Retrieved from www.oapub.org/edu.

[30] Ur, P. (2006). A course in language teaching: practice and theory (13 ${ }^{\text {th }}$ Ed.). Cambridge: Cambridge University Press.

[31] Widia, L. \& Astawa, N. (2014). Improving speaking skill through task-based learning strategies. Journal Santiaji Pendidikan, 4 (1), 35-41.

[32] Willis, J. (1996). A framework for task-based learning. Harlow: Longman.

[33] Wright, T. (2005). Classroom management in language education. New York: Palgrave Macmillan. 

Level

AUTHORS' BIOGRAPHY

Le Van Tuyen, Lecturers of English at the Faculty of English Language, Ho Chi Minh City University of Technology (HUTECH)-Vietnam.

Huynh Hoai An, Lecturers of English at the Faculty of English Language, Ho Chi Minh City University of Technology (HUTECH)-Vietnam.

Citation: Le Van Tuyen, Huynh Hoai An. “Task-based Language Teaching: Task-based Speaking Activities Used in EFL Classrooms at Tertiary Level "International Journal on Studies in English Language and Literature (IJSELL), vol 7, no. 5, 2019, pp. 1-12. doi: http://dx.doi.org/10.20431/2347-3134.0705001.

Copyright: (c) 2019 Authors. This is an open-access article distributed under the terms of the Creative Commons Attribution License, which permits unrestricted use, distribution, and reproduction in any medium, provided the original author and source are credited. 